\title{
US STRATEGIC POLICY TOWARDS INDIA AND PAKISTAN IN POST 9/11
}

\author{
MUHAMMAD MUNIR* - MUHAMMAD AHSAN**
}

\begin{abstract}
This article aims at reviewing the changes that have occurred in South Asia in the post Cold War era after 9/11. In the post 9/11 scenario, US/NATO forces are present in Afghanistan. Indo -US strategic cooperation is rising especially in nuclear field. Pakistan has emerged as front-line state in US global war on terror but has been denied civil nuclear technology by the USA. In view of all these developments the article examines the changing pattern of US interests in South Asia focusing on US strategic policies towards India and Pakistan with special reference to war on terror, nonproliferation of nuclear weapons and US role in crisis management in South Asia. Furthermore, article also examines Indo-US strategic partnership and its implications for Pakistan, in the shape of a disturbed balance of power between the two arch rivals.
\end{abstract}

\section{KEYWORDS}

US Foreign Policy, India, Pakistan, South Asia, Non-proliferation, War on Terror

\footnotetext{
"Muhammad Munir is the Acting Director of Islamabad Policy Research Institute, Islamabad, Pakistan.

** Muhammad Ahsan, PhD, is an Adjunct Professor at Warnborough University, Dublin, Ireland and American University, Washington DC, USA.
} 


\section{Introduction}

The end of the Cold War paved way for a unipolar world, with the United States as the unrivalled global hegemon. Post 9/11 developments provided USA an opportunity to act unilaterally. Key elements of US Strategic Policy were rewritten in the wake of the terrorist attacks on World Trade Centre (WTC) on 11 September 2001.The principal threats to the US and the nature of future conflicts were redefined. ${ }^{1}$ With omnipotent and decisive power, it has become imperative for the United States to pay attention to South Asia as one of the important geopolitical regions of the world.

US ties with India and Pakistan after the demise of the Cold War were miniscule to non existent. However, the 1998 nuclear tests by these two countries were instrumental in highlighting the importance of South Asia to global security. During the following years, the issues of non proliferation remained on top of the US agenda vis-a-vis India and Pakistan. However, the 9/11 terrorist attacks on the United States reinstated the importance of South Asia as an important geopolitical region of the world. This led to a US tilt towards Pakistan in the shape of greater cooperation, greater attention and the status of a valuable ally and partner in the war on terrorism.

However, the recent breakthrough in Indo-US relations which are characterized by the signing of a civil nuclear deal raises many questions. It may not be ignored that such a deal has paved the way for Indian entry into the nuclear club. Nuclear Suppliers Group (NSG) has allowed Nuclear Commerce to India in spite of the fact that India is not a member of Nuclear Non-Praliferation Treaty (NPT). All these factors show an emerging soft corner for India and acknowledgement of its ability to be a responsible de facto nuclear weapons state.

The article is an effort to present a comprehensive analysis covering all dimensions of the US strategic policy towards India and Pakistan after 9/11, finding new parameters added in their relationships in the changed geopolitical environment of post $9 / 11$

${ }^{1}$ Rod Lyon, "The Eagle in a Turbulent World: US and its Global Role", Aspi Strategy Report, September 2008. 
world. Recent discourse about US foreign policy towards India and Pakistan raises many questions about the future of new US security posture in South Asia. Some of the relevant questions are:

- What importance Pakistan and India have in the post 9/11 US strategy?

- How does the United States see India's future role in South Asia?

- Is the new partnership between Washington and Islamabad temporary, immature and unreliable? And how Indian factor affect Pak-US relations?

- Is the US promoting India as a regional power and has the USIndia partnership made Pakistan feel insecure?

The main thesis of this article is that discriminatory US policy towards Pakistan in terms of Indo-US Nuclear Deal would have negative impact on strategic stability in South Asia and Pakistan's commitments to global war on terror. The article has been organized into three main parts, each part having sections and subsection, with the conclusion at the end.

\section{Part-I: Theoretical Understanding of the US Strategic Policy Making}

The theoretical framework of this article is based on the neorealist critique as well as the impact of foreign policy variables on policy making in the international system. The regional, domestic and international variables are taken into account, while analyzing the US foreign policy, as well as the enduring and flexible variables and their influence on strategic policy making. The emergence of the growing US influence after the Cold War as the sole global hegemony has been also taken into account. Similarly, the nature of global relations is analyzed, taking into consideration the contemporary underlying currents of the recent foreign policy debates. Attention is paid to domestic factors in the US, especially the rise of neoconservatives and their growing influence on foreign policy making. 


\section{A. Neorealism and US Foreign Policy}

As far as US foreign policy making in the post 9/11 era is concerned, the influence of neoconservatives on the American foreign policy makers and the United States' unilateralist posture cannot be ignored. The term neoconservative refers to the foreign policy inclinations of President George W. Bush and his advisors, who lay emphasis on a hawkish foreign policy posture, which encourages the use of force to gain foreign policy objectives. Other than the sources of foreign policy analysis, most importantly, the neorealist paradigm shall also be taken into account, in order to understand the rationale behind the US foreign policy making in the post 9/11 world.

Realism has long been used to describe the concepts of anarchy, self help and the balance of power in the international system. However, these concepts have been overshadowed by other concepts, which explain the international system better. Neorealism emerged in the 1970s as a response to the challenges posed by the interdependency theory and also as a corrective to traditional realism's neglect of many aspects. ${ }^{2}$ State behaviour has been interpreted by many theories, some of which have been modified with the changing international environment.

Kenneth Waltz's theory of international politics remains the most influential revision of realist theory in the discipline of international relations. Waltz believes that earlier theories of international relations including classical realism have flaws that can be cured by applying a more scientific approach. According to Waltz, the older realism was restricted to explaining international relations in terms of selfish human nature, whereas his theory of defensive realism rested on understanding the structures of international system. Kenneth Waltz's "neorealism or "structural realism" is a critique of traditional realism. Waltz's neorealism is very relevant in the present world as it breaks apart the units and structure in the international system. The explanation of international behaviour can be found in the systemic constraints on each state rather than their

${ }^{2}$ Scott Burchil and Andrew Linklater, Theories of International Relations, New York, St. Martin's Press, 1996, p. 83. 
internal compositions. The systemic forces homogenize foreign policy behaviour by interposing themselves between states and their conduct. $^{3}$

As compared to Morgenthau and Waltz, John Mearsheimer's theory of offensive realism explains what was missing in their thoughts. Morgenthau could not explain why states are driven to be as aggressive as they are, and Waltz's defensive realism did not adequately describe the constant struggle for power among states, Mearsheimer's offensive realism claims to explain both. States are aggressive due to the anarchic nature of the state system, which leads them to not only seek to ensure their survival, but to also try to acquire power at every opportunity possible. According to the John Mearsheimer, "the structure of the international system is defined by five assumptions that include : 1) states are the key actors in world politics and they operate in an anarchic system, 2) great power invariably have some offensive military capability, 3) states can never be certain whether other states have hostile intentions towards them, 4) great power place a high premium on survival, and 5) states are rational actors who are reasonably effective at designing strategies that maximize their chances of survival."4

Significant changes take place when the number of great powers reduces to two or one. With more than two, states rely for their security both on their internal efforts as well as the alliances they make. ${ }^{5}$ However, the structure of the international system has been restructured by the disappearance of the Soviet Union. ${ }^{6}$ Structural changes affect the behaviour of states and the outcomes produced at the unit level interaction, in terms of nature of distribution of power at the international level. This effect of the change of structure can best be seen in US foreign policy behaviour in the post Cold War era. Our focus is most specifically, in the post 9/11 world, where America behaves unilaterally with unprecedented

\footnotetext{
${ }^{3}$ Ibid.

${ }^{4}$ John J. Mearsheimer, The Tragedy of Great Power Politics, New York, W. W. Norton, 2001, p. 390.

${ }^{5}$ Kenneth N. Waltz. "Structural Realism after the Cold War", International Security, Vol. 25 (1), 2002, p. 5.

6Ibid., p. 86.
} 
show of power.

The fundamentals of American foreign policy from new perspective can be outlined as: maintaining a unipolar world in which the United States has no competitor; no coalition of great powers without the United States will be allowed to achieve hegemony; the United States will not pursue a liberal strategy in which institutions, democracy, and integrated markets reduce the importance of power politics altogether. As a result, America will be the global powerful hegemon, much powerful than other major states that strategic rivalries and security competition among great powers will disappear, thus leaving everyone behind. ${ }^{7}$

The early years of war on terror saw a realignment of relationships among the great powers. Immediately after 9/11, China and Russia supported military action in Afghanistan in order to legitimize their use of force against Islamist militant groups. As can be seen, Bush's message to the world after September 11 was "either you are with us, or you are with the terrorist" compelled many small states to take u-turns in their foreign policies. States like Pakistan withdrew support to the Taliban in Afghanistan.

Summing up the argument, it can be said that the Bush administration's approach to the world "with us or against us" has been based on neorealism to describe the philosophy of the key figures behind the president's foreign policy. Neorealist belief in a muscular foreign policy has dominated the administrations thinking since the $9 / 11$ attacks.

\section{B. Understanding the US Strategic Policy Choices}

Kurt Campbel and Derek Chollet have noted, a conservative administration become an exponent of grand intervention and democracy promotion, while Democrats often sought to distance themselves from precisely those traditional liberal stamping-grounds. Conservative strategic figures pursued courses that threatened the breakdown of the US Army, and placed the administration into rough

${ }^{7}$ G.John Ikenberry, “America's Imperial Ambition”, Foreign Affairs, Vol. 81 (5), 2002, p. 46. 
civil-military waters, while Democrats offered a refuge to disgruntled military officers. ${ }^{8}$

In short, US strategic policies became radically contentious, and not merely because the principle upon which the new policy was apparently based were novel and disconcerting. Critics complained that the core of Bush's policy was ill-defined and unsustainable. Academic commentators, such as Stephen Biddle, insisted that the new strategy had not been well articulated. ${ }^{9}$ And public and congressional support gradually became more fragile for a policy that apparently demanded open-ended engagement, interventions in hostile environments like Iraq, and a continuing flow of US casualties for decades to come.

Scholars disagree over whether - and by how much - US grand strategy has really changed. A broad historical perspective seems to support the notion that Bush has not been the aberration some suppose. For example, Walter Russell Mead (2002) believes that US grand strategy has not changed much in 200 years. ${ }^{10}$ And John Lewis Gaddis (2002) has argued that, while Bush has genuinely reshaped US strategic policy, this must be seen in the context of similar efforts by earlier presidents faced with sudden and destructive attacks upon the US. Both are inclined to see Bush's grand strategy as consistent with the broad sweep of precedents. On the other hand, some insist that Bush has essentially 'undone' US grand strategy. Barry Buzan argues that Bush has burned the stored assets of US goodwill. ${ }^{11}$

\footnotetext{
${ }^{8}$ Campbell K. Chollet, "The New Tribalism: Cliques and the Making of US Foreign Policy”, Washington Quarterly, Vol. 30 (1), 2006-7, pp. 193-203.

${ }^{9}$ S. D., Biddle, “American Grand Strategy after 9/11: An Assessment", Carlisle/Pennsylvania, Strategic Studies Institute, 2005.

${ }^{10}$ Mead W. R., Special Providence: American Foreign Policy and How It Changed the World, New York, Routledge, 2002, p. 54.

${ }^{11}$ B. Buzan, "A Leader without Followers? The United States in World Politics after Bush", <http://fora.tv/2007/11/08/United_States_in_World_Politics_after_Bush/, 14 February 2009.
} 
Immanuel Wallerstein (2002) writes of the eagle having 'crash landed'. ${ }^{12}$ Mead has long been a key supporter of the idea that US foreign policy is not a solo performance but a symphony produced by many players. He argues that 'American foreign policy does not proceed out of a single, unified worldview'.

\section{Part-II: A Historical Overview of US Relations with India and Pakistan}

This part discusses the strategic importance of South Asia for the United States focusing on changing pattern of her policy towards India and Pakistan in the Cold War and the post Cold War years.

\section{A. Strategic Importance of South Asia for the US}

South Asia is a very complex and volatile region, which has long been the focus of many superpowers due to its strategic location. The region is Indo-centric and all six countries of South Asia are located around India, the largest and most populous country. The fact that it is located between the energy rich Persian Gulf and the Asia Pacific and borders Russia and China makes it important in itself and also because it has the potential to affect developments in other areas of considerable importance. ${ }^{13}$

The weakening of the British Empire and the subsequent rise of American might led the Americans to take interest in areas which had the potential to have geopolitical and geostrategic importance. ${ }^{14}$

American strategic interests regarding South Asia were strongly influenced by the British. Sir Olaf Caroe, the last foreign secretary of British India characterized the importance of the Indian

${ }^{12}$ I. Wallerstein, “The Eagle has Crash Landed”, Foreign Policy, Vol. 131, 2002, pp. 60-68.

${ }^{13}$ A. Z. Hilali, US-Pakistan Relationship, England, Ashgate, 2005, p. 3.

${ }^{14}$ Lloyd I. Rudolph and Susanne Hoeber Rudolph, "The Making of US Foreign Policy for South Asia", Economic and Political Weekly, 2006, pp. 703-704, <www.politicalscience.uchicago.edu/faculty/rudolphs/usasia.pdf > , 25 November 2008. 
subcontinent by using a phrase "the wells of power", referring to the oil sources of the middle east in general and of the Gulf and Arabian peninsula in particular. He wanted to use the diplomatic and military resources of the region to secure Middle East oil for the use of America and Europe. ${ }^{15}$

Primarily, the major American interest has been to prevent Communism from spreading to South Asia. Washington's concept of containment, which required a chain of contiguous allies around the perimeter of the Sino Soviet bloc, pushed it towards Pakistan as India did not appear better placed to deal with its problems. This was also partly due to India's announcement of non alignment and its tilt towards the Soviet Union. US policy in South Asia has largely been guided by its global interests and it has tended to view regional conflicts from a global perspective. ${ }^{16}$

All three great powers, Russia, China and the United States have a major interest in South Asia. However, the only one of the three currently to have highly promising relationships with both India and Pakistan is, of course, the United States. ${ }^{17}$

The US interest in South Asia demands management of regional tensions. This also means that relations between India and Pakistan must remain stable. The importance of India and Pakistan remains on top of the American agenda due to their nuclear weapons capability and this involves American nonproliferation interests. ${ }^{18}$ Pakistan has also been accused of nuclear proliferation and this has further brought Pakistan's nuclear program into the limelight.

Apart from this, China's long history of relations with India and Pakistan and also America's concern about foreign interests of China require it to continue involvement in the region. American commitment to human rights and democracy in the region also

\footnotetext{
${ }^{15}$ Ibid., p. 704.

${ }^{16}$ Hilali, US-Pakistan Relationship, pp. 17-20.

${ }^{17}$ Devine T. Hagerty (ed.), South Asia in World Politics, Pakistan, Oxford, 2006, p. 1.

${ }^{18}$ Shirin R. Tahir-Kheli, India, Pakistan and the United States, Karachi, Vanguard, 1998, p. 125.
} 
warrants American attention in the region. ${ }^{19}$ More importantly, US involvement in the region is unprecedented after the September 11 attacks and the subsequent war on terror. Pakistan is a front line state in the war on terror and although India is also an ally in this war, Pakistan remains to be actively involved. Hence, US presence is likely to remain in South Asia due to the continuing war on terror, threat of nuclear proliferation, strained relations between nuclear India and Pakistan, and above all, a threat of religious extremism in the region.

\section{B. Cold War Years}

\section{i. Pak-US Relations: An Opportunistic Relationship}

The history of Pak -US relations has remained quite chequered but the relationship has been sufficiently resilient to sustain the ups and downs, which it experienced during the long period of almost sixty one years. Admittedly relations between states are based on national interests; these can never be assumed to be eternal. It is the convergence of interests, which brings two states close to each other in the fields of cooperation and diplomacy. One thing that is unique in Pak-US relations is that the two countries have conveniently managed to switch over from one shade of relationship to the other and each time their getting together has been accomplished with remarkable ease.

Since independence in 1947, relations between Pakistan and the United States have been a cycle of boom and bust. Probably the single most important factor has been the fact that Pakistan and the West, principally the United States, entered into the bilateral relationship for different reasons: Pakistan joined US-led alliances the Central Treaty Organisation (CENTO) and the South East Asia Treaty Organisation (SEATO) - as an insurance policy in its confrontation with India. Meanwhile, the United States saw Pakistan as yet another sentry post in its Cold War containment of the Soviet

${ }^{19}$ Ibid., p. 126. 
Union. Not surprisingly, therefore, these differing motivations often begat mutual disappointment. ${ }^{20}$

During the brief 1962 Indo-Chinese border war, the US administration provided weapons to India without first consulting Pakistan, and during the 1965 Indo-Pakistan War, the US stopped all shipments of military aid to both countries. This hurt Pakistan much more than India, as the former was wholly dependent on the United States for weapons supplies. In 1971, when India and Pakistan once again fought, this time mainly in East Pakistan, the United States did send an aircraft carrier into the Bay of Bengal. But this was in reaction to India's decision to sign a Friendship Treaty with the USSR. In any case, it did not deter India from dismembering Pakistan, leading to the creation of Bangladesh. For the next few years, relations with the West went into a freeze, especially under the left leaning government of Zulfiqar Ali Bhutto. ${ }^{21}$

However, when the Soviet Union invaded Afghanistan in December 1979, Pakistan became a critical player in Washington's global game. Billions of dollars worth of military and economic aid poured in, and Afghan and Muslim mujahideen were armed and supported by the West and the Arab Gulf states. But when the Soviets left Afghanistan in 1989, Pakistan was once again forgotten, with relations hitting rock bottom following Pakistan's nuclear tests in $1998 . .^{22}$

"Pakistan's relations with the United States have always been based on a transient compatibility of interests, never of comparability." 23 Pakistan was a strong ally of the US during the Cold War. However, at the end of the Cold War, it was facing the adverse effects of anti-Soviet guerilla war and subsequent civil war in Afghanistan, while facing the pressure of millions of refugees, smuggling of weapons and narcotics in the country. This gave birth to

${ }^{20}$ Claue Rakisits, "Engaging Pakistan" Policy Brief, Sydney, Lowy Institute for International Policy, December 2008, < www.lowyinstitute.org>, 14 February 2009.

${ }^{21}$ Ibid.

${ }^{22}$ Ibid.

${ }^{23}$ F. S. Aijazuddin, "The Empty Chair Club", Dawn (Islamabad), 11 July 2003. 
Klashnikov culture, religious extremism, sectarian violence, terrorism, and narcotic addiction. Simultaneously,the US policy makers, instead of addressing the difficulties faced by Pakistan, decided to punish their 'erstwhile ally' by imposing sanctions. The sanctions, meant to curtail nuclear proliferation, had a more severe effect on Pakistan than on India because of the former's less developed economy and its traditional dependence on the US. ${ }^{24}$

There have been many phases in the US-Pakistan relationship during the Cold War years, which range from periods of extreme warmth to periods of stresses and strains. US interests in Pakistan have always been driven by necessity and urgency, an example of which is the Soviet invasion of Afghanistan. There is a difference in the way the two countries look at the relationship. The US looks at the relationship from the global perspective and Pakistan views it from the regional perspective of its dispute with India and as a means to acquire security, stability and economic development. ${ }^{25}$ In nutshell it can be said that partnership during the Cold War years has also been incongruent and unstable.

\section{ii. The United States and India: Estranged Democracies}

The post partition state of India was also required to make a foreign policy choice, just as Pakistan had done in an intensifying Cold War political-military confrontation between the United States and the Soviet Union. As the superpower competition imposed a bipolar structure on international affairs, virtually every country was forced to make a choice. The options included following either of the superpowers or by remaining neutral by forging good relations with both the sides. Indian leaders preferred to stay neutral and made antiimperialism a primary thrust of Indian diplomacy. ${ }^{26}$

The United States viewed India suspiciously as New Delhi extended diplomatic recognition to the People's Republic of China in

\footnotetext{
${ }^{24}$ Noor ul Haq, "Unipolarism and Pakistan-US Relations", IPRI Journal, Vol. 6 (1), Winter 2006, p. 101.

${ }^{25}$ Hilali, US-Pakistan Relationship, p. 231.

${ }^{26}$ Ibid.
} 
1949 instead of the US backed government in Taiwan. This did not come well with the US governments and India's emerging leadership role in the Non-Aligned Movement (NAM) in the 1950's reinforced US doubts. India's neutral posture during the early Cold War period was in stark contrast to Pakistan's strategic choices. Pakistan sought superpower help vis-à-vis India as it was the weaker of the two new countries. By the mid 1950's it was clear that India was not ready to make a Cold War commitment to the US led Western bloc."27 India's anticolonial sentiment was reiterated repeatedly. Thus it became clear that India was not willing to be dictated by the US and did not want the extension of Cold War between New Delhi and Moscow in $1955 .{ }^{28}$

Throughout the 1950's and 1960's, nonalignment was a major force in international relations and India became one of its most prominent campaigner. Moreover, its effectiveness as a conciliator in the East-West competition was circumscribed by unwillingness of American leaders to respect nonalignment as a viable policy and also US annoyance with India acting as its proponent. ${ }^{29}$

The relationship between the two countries during the Cold War years was marked by many ups and downs and the late 1960's were marked by a gradual warming up of relations, despite many set backs in the previous years. President Richard Nixon aimed to have good relations with both India and Pakistan and also wanted to continue substantial economic assistance programs. ${ }^{30}$

India had conducted a nuclear test in 1974 and had claimed that it was for peaceful purposes. However, during this time, aid was suspended to Pakistan on the grounds that it was developing a nuclear weapon. Pakistan resented the American stance as, it was at this time that New Delhi and Washington were engaged in negotiations for the supply of enriched uranium fuel for the nuclear power reactors at

\footnotetext{
${ }^{27}$ Hagerty, South Asia in World Politics, p. 22.

${ }^{28}$ Ibid.

${ }^{29}$ Shirin Tahir-Kheli, India, Pakistan and the United States, p. 2.

${ }^{30}$ Dennis Kux, India and the United States: Estranged Democracies, Washington, NDU Press, p. 280.
} 
Tarapur, near Bombay. Pakistan was displeased at the favouritism. ${ }^{31}$

In short, it can be said that Indo-US relations till 1991 were greatly driven by the strategic calculations of the Cold War. However, during the 1980's, relations had started to improve despite the existence of a measure of mistrust.

\section{The Post Cold War Years}

\section{i. Pak-US Relations: A Bumpy Ride}

The post Cold War years witnessed a new turn in Pak-US relations. After the Soviets pulled out of Afghanistan in 1989, relations between the two countries witnessed a dramatic shift as the United States strategic objectives in the region began to alter. The end of the Cold War also persuaded the US to re-evaluate and downgrade its relationship with Pakistan on the ground that the new global environment did not warrant the old strategic partnership. An immediate and far reaching consequence was the emergence of differences between the two countries on the nuclear issue.

In October 1990, economic and military sanctions were imposed on Pakistan under the Pressler Amendment, a countryspecific law that singles out only one nation on the nuclear issue. One consequence of the Pressler sanctions was the US decision to withhold Pakistan military equipment contracted prior to 1990, worth about $\$ 1.2$ billion, even though Pakistan had paid for this. In Pakistan's perception it was no accident that the application of sanctions coincided with the end of the Cold War. The Pressler sanctions were applied when Pakistan's cooperation was no longer needed following the demise of the Soviet Union. ${ }^{32}$

The majority of the Pakistanis was not happy with the US decision to cut off aid and reacted strongly to these measures. Islamabad saw these measures as selective, discriminatory and

${ }^{31}$ Kux, The United States and Pakistan 1947-2000 Disenchanted Allies, p. 239.

${ }^{32}$ Maliha Lodhi, "The Pakistan-US Relationship," Defence Journal, April 1998. 
detrimental to Pakistan's security. ${ }^{33}$ This punitive action triggered the crisis phase in relations, thus also rendering more difficult the task of making a smooth transition to a post Cold War relationship 19901993 became crisis-ridden years. Instead of the two countries directing their energy and focus to craft a new relationship geared to embracing the future, both became bogged down in fire-fighting one crisis after another in their ties - over the nuclear issue, terrorism and also narcotics. Relations sunk to an all-time low when Washington threatened in 1992/93 to designate Pakistan as a sponsor of terrorism. Then in the summer of 1993 additional sanctions were imposed on Pakistan under the MTCR (Missile Technology Control Regime) for allegedly receiving missile technology from China. ${ }^{34}$

As a result, the bilateral interaction became virtually confined to crisis-management or damage-limitation efforts. The relationship seemed to be a state of free fall. The only silver lining in this downslide was Pakistan-US collaboration in international peacekeeping operations, notably in Somalia. The irony about US nonproliferation policy in South Asia was that while the impetus for proliferation at every step came from India, it was Pakistan, and not India, that was subjected to penalties, embargoes and sanctions.

Perversely Pakistan became the victim of penalties for what India had done in 1974 with its explosion of a nuclear device. US nonproliferation laws such as the 1976 Symington Amendment which was later modified by the 1977 Glenn Amendment, called for halting economic or military assistance to any country which delivered or acquired after 1976 nuclear enrichment materials or technology, unless it accepted full scope safeguards. The Pressler Amendment enacted in 1985, specifically prohibited US assistance or military sales to Pakistan unless annual Presidential certification was issued that Pakistan was excluded from the ambit of American nonproliferation laws.

In May 1999, Kargil Crisis caused a limited conflict between India and the US. With the US involvement, the issue was resolved; but resulted in a friction between the military and the civil

\footnotetext{
${ }^{33}$ Hilali, US-Pakistan Relationship, p. 234.

${ }^{34} \mathrm{Kux}$, The United States and Pakistan..., p. 319.
} 
government that led to military take over. Military take over resulted in imposition of sanctions against Pakistan.

In 2000, President Clinton visited South Asia. He spent five days in India and the visit was highly successful and indicative of a new chapter in Indo-US relations. After India, Clinton arrived in Pakistan for a mere five hours and met with the chief executive, General Pervez Musharraf. The trip to Pakistan was very different and President Clinton suggested on lowering the temperature on Kashmir, by reining in terrorist groups, by pressurizing the Taliban and also by undertaking the nonproliferation measures. Musharraf was unable to give a timetable for return to democracy in Pakistan although he expressed his intention to do so. Clinton urged Pakistan to move away from the conflict, avoid isolation and instead address the needs of the people. However, the message was clear that India had taken precedence over Pakistan, and in US eyes, India was the chosen country.

\section{ii. Indo-US Relations: A Reawakening}

India's virtues of non alignment were shattered with the end of the Cold War. As the Cold War was ending, by the mid 1980s, the United States had begun to treat India as a significant Asian power with which the United States should seek friendly relations, including expanded security cooperation. India's size, growing economy and military prowess reiterated its importance strategically as well as economically for the US, which had started to downgrade its relationship with Pakistan with the demise of the Soviet Union. In New Delhi as well, there was a desire for better relations with the United States after the end of the Cold War. ${ }^{35}$

The US interest in furthering contacts between its armed forces and those of India is evident from high level exchanges and also the holding of joint naval exercises . The distant relationship of the Cold War period was transformed into one of cooperation and enhancement of ties between the two powers. The shift in US perceptions in favour of India caused concern and resentment in

\footnotetext{
${ }^{35} \mathrm{Kux}$, India and United States, p. 44.
} 
Pakistan. Despite the end of the Cold War, India and Pakistan remained a focus of US concerns on account of the nuclear capability and also because neither country had signed the NPT.

India attracted US investment and trade during 1993-94 than ever before. This along with increasing economic ties and military cooperation paved the way for a new security partnership. The United States, in the post Cold War era, emerged as the preeminent candidate for such a partnership. Many factors worked in favour of such a partnership. Despite the American alliance with Pakistan, India was never completely ignored by the US. As mentioned above, mounting economic ties, not just in trade and investment, but also in symbiotic development of information technology industries; an increasingly large, well educated and politically influential Indian diaspora community in the United States and overlapping strategic interests, all paved way for better ties with the US. ${ }^{36}$

Relations between the two countries saw an upward trend in 2000, when the American president had undertaken a trip to South Asia. The marked difference between the treatments meted out to India was evident from the fact that President Clinton spent five days in India as compared to five hours in Pakistan.

\section{Part-III: US Strategic Policy towards India and Pakistan in post $9 / 11$}

There is no doubt that 9/11 tragedy was a paradigm shift event for the whole global security environment, not just for Americans but also for other countries. Winston Churchill once said, "But great battles, won or lost, change the entire course of events, create new standards of values new moods, new atmospheres, in armies and in nations, to which all must conform." The US-led international coalition's war against terrorism in Afghanistan and other parts of world specially US unilateral war on Iraq has totally changed the concept of international security and world politics. The post 9/11 events have also altered the strategic dynamics of Southwest Asian region especially due to US military involvement in Afghanistan. Post

${ }^{36}$ Hagerty, South Asia in World Politics, p. 137. 
9/11 has created severe crises for the whole world but the Muslim world suffered the most. ${ }^{37}$ The tragedy of 9/11 was condemned by the Islamic world and most of the Muslim countries even joined the US led coalition against terrorism and fully cooperated in its war on terror but certain lobbies in USA and west started a systematic campaign to malign Islam as a religion of terror and Muslims as terrorist. ${ }^{38}$ This part analyses the changing patterns of US strategic policies towards Pakistan and India.

\section{A. Pak-US Relations in the post 9/11 Era: A New Beginning}

The 9/11 attacks on the World Trade Center and the Pentagon opened a new chapter in Pak-US relations and have changed much for Pakistan, domestically as well as internationally. Although September 11, 2001 was an uneventful day in Pakistan, however, it was to change the future course of events in the region and the world itself. On the eve of September 11, 2001, Pakistan was an internationally isolated state, with a stagnant economy, a military government, international pariah status and political and social institutions in Disney. ${ }^{39}$ Thus a new era dawned in Pak-US relations which dictated changes in Pakistan's domestic politics as well as changes in its relations with other countries and groups.

Ironically, it was after 11 September 2001, that Pakistan's strategic importance was again realized by the US. Pakistan acquired a favourable status after President Musharraf's decision to side with the US after reversing the pro-Taliban policy of his predecessors and agreed to US demands, which included over-flying rights, logistical support, intelligence sharing, etc. ${ }^{40}$ It made available to Pakistan, US financial, security and economic assistance. However, India "benefited strikingly from the US-led war on terrorism and the US

${ }^{37}$ Muhammad Ahsan, "Post-9/11 Islamphobia: Promoting Interfaith Harmony and Global Peace”, IPRI Journal, Vol. 5 (1), Winter 2005, p. 1.

${ }^{38}$ Muhammad Munir, "Challenges for the Muslim World", Pakistan Observer, 13 May 2006.

${ }^{39}$ Stephen P. Cohen, The Idea of Pakistan, Lahore, Vanguard Books, 2005, p. 90.

${ }^{40}$ For details see, Bob Woodward, Bush at War, New York, Simon\&Schuster, 2002, pp. 58-59. 
military actions in Afghanistan with respect to its leverage on Kashmir, at the expense of Pakistan." 41 It was able to strengthen its occupation of the state of Jammu and Kashmir by stigmatizing the freedom struggle in Kashmir as "terrorism" and armed freedom fighters as "terrorists".

At the same time, the Indian policy of isolating Pakistan suffered a setback. India was opposed to the Pak-US relations from the beginning. The reason why India was opposed to Pak-US alliance, as stated by the British Secretary of States for India Lord Listowel, was that the Indians were against Pakistan fortifying itself with assistance from America, Britain or any other power. ${ }^{42}$ With a view to denying foreign support to Pakistan, anti-Pakistanism in the US and elsewhere and anti-Americanism in Pakistan is in consonance with the Indian strategy.

\section{i. Determinants of Pak-US Relations}

Before 1989, Pakistan was "a strategic ally of the US and fought a war in Afghanistan for 10 years." Then it was left "high and dry". The United States then started to develop a "strategic relationship with India, which was in the enemy camp. What would the man on the street [in Pakistan] think?"43 After the Cold War, the US retained limited tactical interest in Pakistan. The post 9/11 US involvement in Afghanistan and its presence in Central Asia and the Middle East increased the geostrategic importance of Pakistan for the US. The US needs Pakistan's immediate support in its war against $\mathrm{Al}$ Qaeda and Taliban in Afghanistan.

As a long term measure, the main US concerns centre around enlisting Pakistan's cooperation in the war against international

${ }^{41}$ Rodney W. Jones, "United States and South Asia: Core Interests and Policies and their Impact on the Security and Economic Development of the Regional Countries", paper presented at the International Seminar on Major Powers and South Asia, Institute of Regional Studies, Islamabad, 11-13 August 2003.

42“"Lord Listowel (Secretary of State for India) to Lord Mountbatten (Indian Viceroy), 27 June 1947”, Mountbatten Papers, IOR: MSS. Eur. F.200/176.

${ }^{43}$ Pervez Musharraf, Time, 25 September-3 October 2005, p. 14. 
terrorism; non-proliferation of nuclear and missile technology; destruction and elimination of weapons of mass destruction (WMD) in possession of hostile states, radical extremists and terrorists; democratization; human rights, moderation and enlightenment as opposed to fundamentalism, religious extremism, militancy and armed violence; and freezing of tension in South Asia. ${ }^{44}$ Other US concerns may relate to such issues as money laundering, drug smuggling and arms trafficking.

\section{ii. Fight against International Terrorism}

Pakistan has no choice but to support international war on terror. Its policy response, besides supporting the US, lies in its own enlightened self-interest. It is best reflected in the remarks, President Musharraf made in a press conference on 16 October 2001:

We joined the world community in offering cooperation to bring perpetrators, organizers and sponsors of the terrorist attacks to justice. $\ldots$ The extraordinary session of the OIC Foreign Ministers held on $10^{\text {th }}$ of October has endorsed this position. ... the root causes of most acts of terrorism lie in political oppression and denial of justice. In order to achieve durable results, the current war on terrorism must address and eliminate its causes. ${ }^{45}$

However, it is generally perceived that the US tends to make no distinction between terrorism and genuine freedom struggle in the state of Jammu and Kashmir or Palestine. Religious elements, therefore, consider that the US policy is hardly based on just and moral principles but on sheer double standards. A similar feeling is succinctly expressed differently by Mohammed el-Sayed Said, Deputy Director of Al Ahram think-tank in Cairo, who says that the US "need to act like any respectable commander or leader of any army. They can't just project an image of contempt for those they wish to lead." 46

\footnotetext{
${ }^{44}$ Jones, "United States and South Asia...".

${ }^{45}$ Dawn (Islamabad), 17 October 2001.

${ }^{46}$ Vexan Crabtree, "Why do People Hate America? A Summary of AntiAmericanism", 24 September 2001, 〈http://www.new.bbc.co.uk>, 14 February 2009.
} 
Pakistan's joining the war on terror, has been appreciated all over the world. India's past efforts to declare Pakistan a "terrorist" or "terrorist sponsoring state" has failed. Instead, Pakistan is acknowledged as a "front line" state in the war against international terrorism. The 9/11 Commission Report states:

Pakistan actively assisted: its authorities arrested more than 500 al Qaeda operatives and Taliban members, and Pakistani forces played a leading part in tracking down KSM [Khalid Sheikh Muhammad], Abu Zubaydah, and other key al Qaeda figures. ${ }^{47}$

Yet, Pakistan's image is somewhat clouded by media coverage of political Islam, and the misperception in distinguishing mainstream Islamist organizations that are peaceful, from terrorists who invoke the sacred name of Islam, as a justification for violence. The latter category was born and strengthened during the Afghan War against the Soviets and unfortunately its negative fallout affected Pakistan. However, such elements are a microscopic minority and mostly remain entrenched near Pak-Aghan borders, but their size and strength is blown up in the media, thus bringing a bad name to Pakistan. Pakistan is making an extra effort to hunt down those who advocate hatred and violence. It is crucial for Pakistan to put its own house in order, by clamping down hard on elements advocating militancy and extremism. ${ }^{48}$

\section{iii. Strategic Partner or a Target: Operations in FATA and Impact of US Strikes}

Since 2003, Pakistan's army has conducted unprecedented and largely ineffectual counterterrorism operations in the country's Federally Administered Tribal Areas (FATA) bordering Afghanistan, where Al Qaeda operatives and pro-Taliban insurgents are said to enjoy "safe heaven." Militant groups have only grown stronger and more aggressive in 2008. Islamabad's new civilian-led government vows to combat militancy in the FATA through a combination of

479/11 Commission Report, New York, W. W. Norton\&Company Inc., p. 368.

${ }^{48}$ Noor ul Haq, “Unipolarism and Pakistan-US Relations”, p. 105. 
military force, negotiation with "reconcilable" elements, and economic development.

Prior to 2007, the United States had praised the government of then-President Pervez Musharraf for Pakistani accomplishments against Al Qaeda, including the arrest of over $700 \mathrm{Al}$ Qaeda figures, some of them senior, since the September 11 attacks. After the attacks, Pakistan provided the United States with access to Pakistani airspace, some ports, and some airfields for Operation Enduring Freedom. Others say Musharraf acted against Al Qaeda only when it threatened him directly; for example, after the December 2003 assassination attempts against him by that organization. The US shifted toward a more critical position following a New York Times report (February 19, 2007) that Al Qaeda had re-established some small Al Qaeda terrorist training camps in Pakistan, near the Afghan border.

The Pakistani military has in late 2008 undertaken major operations aimed at neutralizing armed extremism in the Bajaur agency, and the government is equipping local tribal militias in several FATA agencies with the hope that these can supplement efforts to bring the region under more effective state writ.

In the meantime, the US military in the last few months has launched a series of missile attacks by US Predator drones. For example, between December 2007 and August 2008 there were only six US missile attacks in FATA but since August 2008 there have been 19 or so. The latest one was in Bannu in the settled area of NWFP. 49

Whether these are jointly coordinated by the US and a Pakistan military remains a hot and debatable issue in Pakistan. It is thought in some quarters in Pakistan that there is "tacit agreement" between the two militaries to squeeze the terrorist from both sides.

Pakistani government, on its part, has criticized these cross border violations of Pakistan's sovereignty and territorial authority but to no avail. On the other hand, the US authorities has neither

49“The Smart Middle Way”, Daily Times, 18 November 2008, p. 7. 
denied nor claimed about these strikes but has acknowledged that the policy has blocked infiltration of militants inside Afghanistan and put them under pressure from Pakistan army who are dealing with the insurgency in Bajaur tribal agency.

Fresh reinforcement of nearly 20,000 troops are being sought to strengthen US forces in the south and south eastern terrorist hit regions of Afghanistan. ${ }^{50}$ Thus increasing the number of troops in Afghanistan to about 58,000 from the current level of 34,000 and add to the approx 34,000 NATO led troops that are already operating there. The US has more than 19,000 soldiers under NATO command and another 16,000 in a separate counter-terrorism force in eastern part of the country. It is thought that the Afghan forces will ultimately have to shoulder responsibility before NATO forces start thinning out which may take ten years or so to establish stability as Afghanistan is a "theme park of problems."

A key, according to US commanders, is to reduce militant infiltration into Afghanistan from Pakistan. To do so, US General David McKiernan, the overall commander in Afghanistan, is "redefining" the Afghan battlefield to include the Pakistan border regions, and US forces are becoming somewhat more aggressive in trying to disrupt, from the Afghan side of the border, militant operational preparations and encampments on the Pakistani side of the border. ${ }^{51}$ Gen. McKiernan and other US commanders are trying to rebuild a stalled Afghanistan-Pakistan-US/NATO military coordination process, building intelligence and information sharing centers, and attempting to build greater trust among the senior ranks of the Pakistani military. 52

${ }^{50}$ Currently the US has about 19.000 troops under NATO command in Afghanistan and another 16.000 as a separate counter-terrorism force in eastern part of the country. See, "Afghan Strategy Poses Stiff Challenges for Obama", The New York Times, 19 July 2008.

51"Islamist Militancy in the Pakistan-Afghanistan Border Region and US Policy", CRS Report for Congress, RL34763, 21 November 2008.

${ }^{52}$ Ibid. 


\section{iv. Non-Proliferation of Weapons of Mass Destruction}

There is an increasing concern in the US about WMD proliferation. This fear is intensified due to the apprehension that these weapons may be used against it as in $9 / 11$.

Clandestine nuclear proliferation activities are prevalent all over the world, especially in the developed countries with scientific and technological know-how. ${ }^{53}$ In Pakistan an individual, Dr A. Q. Khan, may be guilty, the state is certainly not involved. In any case, it is a closed chapter. However, the anti-Pakistan forces are working hard to target the country itself. Pakistan is continuing to assure the global community that it scrupulously adheres to its declared nonproliferation policy.

\section{v. Freezing of Tension in South Asia}

The US is interested in sustainable peace in South Asia. It desires resolution of longstanding and festering disputes between India and Pakistan, including that of the state of Jammu and Kashmir. This is to avoid nuclear war and destruction, which goes against its global strategy. At the same time, the US wants India to become a major power. Perhaps, the US would not like to see Pakistan strong enough where it could challenge the preeminent regional and global status of India. This might be the reason why the cutting edge of the military arsenal is made available to India, directly or through Israel, but grudgingly given to Pakistan. At the same time, the US would not like to weaken Pakistan to an extent that it is balkanized, or made into a client state of India, because in such a situation it could not play the Pakistan card against India or vice versa. ${ }^{54}$ From a South Asian perspective, there is a requirement for economic stability and progress as well as ensuring a balance of power in the region. However, Pakistan should not be very apprehensive of the new amity between India and the US. Pakistan Foreign Office spokesman, Masud Khan, has described the growing US-India close relations as a

${ }^{53}$ Dawn $\quad$ (Islamabad), $22 \quad$ February 2004, <http://www.dawn.com/2004/02/22/ed.htm>, 14 February 2009.

${ }^{54}$ Touqir Hussain, "Washington's Term of Engagement", Dawn (Islamabad), 6 September 2003. 
"window of opportunity which could help persuade New Delhi to cooperate with Islamabad in developing a working relationship for bringing peace and stability to the region." 55 Christina Rocca, US Assistant Secretary of State for South Asia, while in New Delhi in September 2003 said:

Pakistan is a country in the midst of a major political, economic and ideological transformation. It has not yet safely escaped the dangers of serious crisis on multiple fronts. It must be assisted to achieve a softlanding that corrects disturbing internal trends, realigns its direction as a moderate Muslim state, and defeats definitively all terrorism emanating from its soil. We believe Indians should welcome such assistance, and I know that many do. ${ }^{56}$

The US seems keen to build up a long-term partnership with India to promote its strategic and economic interests. It would like détente if not friendship between India and Pakistan, so that South Asia is built up as a counterweight against the rising power of China. In fact, it is in the interest of the US that there is no conflagration between the two neighbours. Pakistan also needs peace, so that it could develop fast in the competing world of $21^{\text {st }}$ century for the betterment of its people. At the same time, it needs to maintain its deterrent capability in nuclear and conventional weapons and simultaneously set its own house in order by strengthening itself through economic progress and political empowerment.

\section{vi. Future Outlook of the US Policy Towards Pakistan}

The election of Barak Obama as the $44^{\text {th }}$ President of the US in November 2008 is felt as a breath of fresh air world wide. It was particularly received with exhilaration by the Islamic, African and Latin world. In South Asia, especially in Pakistan it was greeted with joy and high hopes. People by and large nurse expectations that Bush's arrogant policies of unilateralism, intimidation and use of force might now give way to more temperate and sensitive policies leading to a more peaceful world. No doubt democrats are generally pro-democratic than republicans. In case of Pakistan there is an

${ }^{55}$ Dawn (Islamabad), 16 September 2003, p. 16.

56Ibid., 12 September 2003. 
elected political government in office following general elections of February 2008 which saw the ouster of President Perveiz Musharraf. This government has come into power through generally accepted fair and free elections with moderate parties now in power.

During the US electioneering Obama's speeches were tough on Pakistan as he was critical of Pakistan's role in the war against global terrorism stating that on "actionable intelligence" and failure of Pakistani government to deal with it would have no qualms to strike terrorist havens in the tribal areas. He was also critical of Pakistan 'using the US assistance to train armed terrorists for infiltration into and talked of accountability and performance of nearly $\$ 12$ billon aid to Pakistan over the last seven years. Lately, however he has considerably modified his stance saying that it would be better to work with Pakistan and perhaps increase non-military aid and increased economic aid for better performance. Also, nearly three brigade level of additional troops may be sent to beef up the present US forces to a level of 50,000 by spring $2009 .{ }^{57}$ At the same time, more emphasis would be laid on monitoring of borders, control of narcotics and corruption that are fuelling the insurgency. He is also coming around to the view that based on Iraqi experience certain 'moderate' Taliban elements may have to be co-opted for peace in the region. President-elect Obama asserts that his government will follow a comprehensive and integrated approach to Pakistan. He said that he will "pursue a tough, smart and principled national security strategy - one that recognises that we have interests not just in Baghadad, but in Kandahar and Karachi, in Tokyo and London, in Beijing and Berlin." 58 His main five goals of making America safer are: ending the war in Iraq responsibly; finishing the war against Al-Qaeda and the Taliban; securing all nuclear weapons and materials from

\footnotetext{
${ }^{57}$ This has been confirmed by Defence Secretary Robert Gates. According to him, it would take 3-4 years for Afghan forces to reach a 'tipping point' leading to less reliance on some 70,000 foreign troops. See, "US to Deploy Three More Combat Brigades in Afghanistan", Dawn (Islamabad), 12 December 2008.

58“Obama's Remarks on Iraq and Afghanistan”, 15 July 2008, <http://www.nytimes.com/2008/07/15/us/politics/15test-obama.html?sq obama\%20and\%20South520Asia@st=cse\&scp=21\&pagewanted=all $>$, 14 February 2009.
} 
terrorists and rogue states; achieving true energy security, and rebuilding our alliances to meet the challenges of the $21^{\text {st }}$ century." 59

The US military thinking about South Asia is that terrorism in Afghanistan is closely linked with the India-Pakistan dispute over Kashmir. In other words, any settlement of Kashmir dispute might enable Pakistan to direct its forces and energy on counter-terrorism rather than remain obsessively focused on India. It is now increasingly felt that paucity of US and NATO troops and Pakistan's incapacity for poor control over its FATA regions and Pak-Afghan border is a serious issue. In this regard, Bruce Reidel, a former CIA officer has characterised Pakistan as "the most dangerous country in today's world." 60 There are strong fears in US policy circles that the next attack on the US mainland could originate from the Pakistan's tribal regions. Obama and his advisers have endorsed Congressional efforts to provide a more equal balance between military and nonmilitary aid to Pakistan. Since September 2001 the US has provided approximately $\$ 11$ billion in assistance to Pakistan including about $\$$ 6 billion in "coalition support funds" to reimburse the Pakistani military for its contributions for Operation Enduring Freedom. ${ }^{61}$

\section{B. US Strategic Policies towards India in Post 9/11}

\section{i. Indo-US Strategic Cooperation-New Beginnings}

The major South Asian power, India, during the Cold War, propounding the philosophy of non-alignment, did not ally itself with either superpower but exploited both to its advantage. After the collapse of the Soviet Union, India turned towards the United States. The liberalized economic policies for repatriation of capital from India attracted US multinational corporate investments in India that offered a vast market. The US economic interest, coupled with strategic objective to contain China, helped in reversing the coolness in Indo-US relations and brought them closer. This was a primal

\footnotetext{
${ }^{59}$ Ibid.

${ }^{60}$ As cited in Richard Weitz, "Obama Team Ponders New Approach to Pakistan", CACI Analyst, 26 November 2008, <http://www, caianalyst.org/?q=node/4988>, 14 February 2009.

${ }^{61}$ Ibid.
} 
factor for India attaining the status of a "strategic partner" of the US resulting in the US-India defence agreement signed in June 2005.

India, on its part, made a significant departure from its proArab policy in the Middle East by upgrading its diplomatic presence in Israel to ambassadorial level in 1992. This opened an "unexploited avenue" for boosting its economy and security, besides giving a further fillip in its relations with the US. The neo-conservatives supporting President Bush administration and the well-established Jewish lobby in the US, preferred looking at Pakistan through an Indian prism.

Thus, a glaring change in US policy was that "US dropped its long established practice of attempting to maintain 'even-handedness' between India and Pakistan on matters related to their respective security concerns." 62 In fact, there seemed a reversal of the US policy. During the Cold War, there was a tilt in favour of Pakistan and after the war the tilt changed sides in favour of India. A significant demonstration of this policy was made in 1999 when President Clinton paid a five-day visit to India but restricted his visit to Pakistan to only five hours.

The conservative President George W. Bush administration, which came to the White house in January 2001, was determined to substantially alter the US strategic plan for four distinctly separate regions: 1) relations with the European Union; 2) new security architecture and its scope; 3) new approach for China: from constructive engagement to strategic competition; 4) strengthening relations with India and downgrading the traditional relations with Pakistan. Clearly, before 9/11 the Bush administration's policy toward South Asia was to continue to tilt toward India, and downgrade its relations with Pakistan.

The Indian reaction to Bush's concept of the new world order was enthusiastically supportive; Europe's was cool, and the Chinese opposition was loud and clear. China saw that the implications of this strategic design were directed to inhibiting its growth as a military superpower. Why was India so enthusiastic? Several explanations can

${ }^{62}$ Jones, "United States and South Asia...". 
be offered: 1) India wanted the US to lift the sanctions imposed over nuclear explosions; 2) India wanted US support to gain a permanent seat on the UN Security Council; 3) India was keen to replace Pakistan as Washington's strategic partner in South Asia; 4) India desired to capitalize on growing economic ties between the two countries, driven by the increasing contributions of Indian-American engineers and entrepreneurs in the high-technology sector. ${ }^{63}$

By June 2001 the Bush Administration had taken significant steps to improve the relationship with India. In the military to military dimension the US initiated one joint military exercise or engagement each month. These exercises covered a wide range of military skills and attempted to improve the capacity for combined military operations across the board - by Special Forces against terrorists, maritime interdiction, search and rescue, airlift support, logistics transport, and airborne assault. In June and July 2002, the Indian Navy ships Sukanya and Sharda conducted escort patrols for American ships through the Malacca Straits, in support of Operation Enduring Freedom Afghanistan. American warships began to refuel in Chennai and Mumbai. The largest ever US-India naval exercise was conducted in September 2002. In 2003 more than 180 highranking leaders from the Indian security community attended conferences sponsored by the US Department of Defence.

Delivering a luncheon address before the Confederation of Indian Industry in New Delhi in 2003, the US Ambassador Robert D. Blackwill paid the most flattering compliment to the Indian military: 'Indian and American soldiers are warriors. Their central mission is to fight and win wars. How many armies can one say that about today?' In 2001 and 2002, many Pakistanis were deported from the US whereas the US consular offices in four Indian cities issued more than half a million business and tourist visas to Indian citizens. The visa issuance rate for India was the same as it had been before $9 / 11 .{ }^{64}$

In May 2001 Deputy Secretary of State Richard Armitage, to add insult to injury to Pakistan, just barely stopped short of directly

${ }^{63}$ Roger Cohen, "What the World Wants from America", The New York Times, 11 January 2005.

${ }^{64}$ Robert D. Blackwill, "The Future of US-Indian Relations", speech of 17 July 2003 in New Delhi. 
naming Pakistan as a rogue state in a press conference in India. Asked to name rogue states, he referred to Libya, Iraq, North Korea, and other countries 'in your neighbourhood'. When pressed to elaborate, he said: 'We have questions about Pakistan which are well known, and of which you are equally aware.' ${ }^{65}$ Armitage was in New Delhi to seek support from the Indian government for Bush's ideas on the new strategic framework for global security. He declared the start of a new relationship between India and the US. He called on Prime Minister Vajpayee and handed over a letter from Bush accepting the invitation to visit India in the near future. Also Bush assured Vajpayee that he intended to work closely with him to "promote common interests in Asia and beyond. ${ }^{66}$

The current relationship assumes much significance not only for India and the United States, but also for the world at large. The process began with the Kicklighter proposals of 1991 which paved the way for defence consultative groups, combined naval exercises (1992) and 'Agreed Minutes on Defence Relations' (1995). The defence ties of the 1990s remained measured and cautious, however, clearly devoid of strategic underpinnings; and were further hampered by the India's 1998 nuclear tests. But the 'Pokhran-2 rift' did not last long. The turn of century witnessed a visible intensification of relations, as indicated inter alia by the reinvigoration of the consultative groups (late 2001), commencement of combined exercises between armies and air forces (2002), India's escort of US ships in the Malacca Straits (2002) and coordination of tsunami operations (2004-05). These culminated in a 10-year Defence Framework Agreement (June 2005) to further advance ties. More recently defence interactions have acquired greater momentum through US defence sales to India, high-level visits, training exchanges, and combined exercises. The United States wants to go even further, as evident from its efforts to bring India into arrangements like the Proliferation Security Initiative (PSI) and Logistics Support Agreement (LSA). ${ }^{67}$

65"Bush Proposals Aimed at Rogue States: Armitage", The Hindu, 12 May 2001.

${ }^{66}$ Ibid.

${ }^{67}$ Gurpreet S. Khurana, "India-US Combined Defence Exercises: An Appraisal", Strategic Analysis, Vol. 32 (6), November 2008, pp. 1047- 


\section{ii. 9/11 and Indo-US Counter-Terrorism Cooperation}

Following the 9/11 attacks India offered substantial support to the United States in its counter-terrorism efforts in Afghanistan. This included 'the use of numerous Indian military bases, an offer that was never made even to the erstwhile Soviet Union, which functioned as New Delhi's patron during the last decades of the Cold War. India also provided satellite imagery of Afghanistan to the United States before the initiation of the US-led Operation Enduring Freedom (OEF). The Indian Navy contributed to the US effort during OEF by escorting vessels carrying cargo for military operations through the Strait of Malacca and the Andaman Sea. ${ }^{68}$

During Prime Minister Manmohan Singh's visit to Washington, his July 18 joint statement with President Bush reiterated the need to 'combat terrorism relentlessly' through 'vigorous counter-terrorism cooperation'. The declaration reinforced the previously concluded June 28, 2005 defence pact between the two countries that called for strengthening their militaries' capabilities to 'promote security and defeat terrorism'. 69

The process was carried forward during President Bush's three-day trip to India in March 2006, where he discussed further strengthening of a bilateral 'global partnership'. The Joint Statement issued on that occasion 'noted the enhanced counter-terrorism cooperation between the two countries and stressed that terrorism is a global scourge that must be fought and rooted out in every part of the world'. ${ }^{70}$

1048.

${ }^{68}$ Ian Storey, "Indo-US Strategic Ties on the Upswing", Jane's Intelligence Review, March 2003, pp. 40-43.

${ }^{69}$ See, "Joint Statement between President George W. Bush and Prime Minister Manmohan Singh", Office of the Press Secretary, 18 July 2005, <http://www.whitehouse.gov/news/releases/2005/07/20050718-6.html>, 26 December 2008.

${ }^{70}$ See, "US India Joint Statement: President's Visit to India and Pakistan", Office of the Press Secretary, 2 March 2006, <http://www.whitehouse.gov/news/releasE03/20060302-5.html>, 27 January 2008. 
The need for greater ties with India has been stated periodically by US officials, In April 2007 Under Secretary of State for Political Affairs, Nicholas Burns, published an opinion article in the Washington Post lauding stronger Indo-US relations and calling for 'two more giant steps' that must be taken to achieve a global partnership, greater bilateral counter-terrorism cooperation and a stronger military partnership that includes defence sales. ${ }^{71}$

The bilateral defence cooperation between the United States and India, which had grown significantly by 2004 , is viewed by US diplomats as among the most important aspects of the transformed relations between the two countries. US policy-makers essentially view defence cooperation with India in the context of 'common principles and shared national interests' such as defeating terrorism, preventing weapons proliferation and maintaining regional stability. The need and future potential to expand military cooperation with India emphasized by key US commanders. In April 2007 the head of the U Command, Admiral Tim Keating, stated before a Senate panel that the Pentagon intended to 'aggressively' pursue expanding military-to-military relation with India. ${ }^{72}$

India and the United States have thus embarked on cooperative endeavours in the military and political spheres. Both have launched numerous counterterrorism initiatives and have undertaken a wide spectrum of joint military exercises. Along with increased military cooperation, US arms sales to India have gathered increased momentum. ${ }^{73}$ Greater military-to-military ties have included company-level joint counter-insurgency training of army units and since 2002 India and the United States have held a number of naval, air, and ground exercises. In October 2006, a company of US marines travelled to India for a counter-terror exercise with the

\footnotetext{
${ }^{71}$ Nicholas Burns, "Heady Times for India and the US", Washington Post, 7 April 2007, <http://www.washingtonpost.com/wp-dyn/content/article/:27/ AR2007042702014.html>, 23 December 2008.

72“"New Framework for the US-India Defence Relationship", Washington, DC, 28 June 2005,

<http://www.indianemba press_release/2005/June/31.htm>, 21 January 2008.

${ }^{73}$ Rajat Pandit, "India Eyes \$ 2 Billions Defence Deal with US”, The Times of India, 29 January, 2008, p. 1069.
} 
Indian army. In September 2006 the Indian Army sent a company to Hawaii to train with US Army Pacific forces. Before that, in August, Indian Army had sent two experts to observe a military exercise in Hawaii. ${ }^{74}$ Both countries scheduled at least five joint combat exercises in 2008. In addition, Special Forces from both countries have focused on high-altitude operations and training in Jammu \& Kashmir and near the India-China border. Several US army personnel have undertaken jungle terrain training at the CounterInsurgency and Jungle Warfare (CIJW) School in Vairangte in India's north eastern state of Mizoram. The US assistance provided to India under International Military Education and Training (IMET) has increased three-fold since 2000, although in 2006-2007 there was a marginal decrease. ${ }^{75}$

\section{iii. Implications of Indo-US Nuclear Agreement}

The US-India nuclear deal, which took off as an agreement between the two heads of state in July 2005, has changed the bilateral relationship in a significant way. ${ }^{76}$

The India-US civil nuclear deal has been painted in India by its supporters as necessary for securing fuel and technology for India's nuclear energy programme and nothing else. However, the US officials have made it clear from the beginning that lifting nuclear sanctions was a concession they were willing to give India in lieu of India entering into a "strategic partnership" with the US. In addition, selling India reactors from their moribund nuclear industry also meant

74"Country Reports on Terrorism", Office of the Coordinator for Counterterrorism, 30 April 2007, <http://www.state.gov/s/ct/rls/Cl B2734.htrn>, 21 December 2008. Also see, "Exercise Cope India 04", <http://indianairforce.nic.in/sh>, 14 February 2009.

${ }^{75}$ Shanthie Mariet D'Souza, "Indo-US Counter-Terrorism Cooperation: Rhetoric versus Substance", Strategic Analysis, Vol. 32 (6), November 2008, p. 1070.

${ }^{76}$ Ramianu Malika, "India-US Relations in the Shadow of an Uncertain Nuclear Deal", Asian Journal on Terrorism and Internal Conflicts, Vol. 11 (41), October 2008, p. 17. 
billions of dollars in orders and thousands of jobs for Americans. ${ }^{77}$ Condolezza Rice, testifying before the Senate Foreign Relations Committee on 5 April 2006 stated that:-

This initiative will create opportunities for American jobs. Nuclear cooperation will provide a new market for American nuclear from [...] The initiative may add as many as three to five thousand new direct jobs in the United States and about ten to fifteen thousand indirect jobs in the United States, as the United States is able to engage in nuclear commerce and trade with India.

The larger strategic vision that the US has on Asia is spelt out in its various strategic documents. It has identified India as a crucial strategic partner in Asia and the nuclear deal as a key element in this strategy. William J. Burns, under secretary of state for political affairs stated on 18 September 2008 that the nuclear sanctions were the principal obstacle in India-US relations. "By addressing, and thus surmounting, the principal obstacle that has, for decades, stood in the way of better relations, the nuclear agreement is not only important on its own terms but has moved our relations farther and faster forward than any other step." 78

The US-India nuclear deal has also exposed Washington's favouritism in dealing with India. As India is not a signatory to the NPT, it is unofficially recognized as a nuclear power. President Bush sees India as a friend in pushing onward US global policy goals, from free trade to democracy and energy cooperation as well. The nuclear deal has greatly upset Pakistan, an important ally in the war on terror. This shows that the US has the propensity for unilateral actions with little or no regard for consequences for regional stability and balance of power.

The nuclear deal with India is not only bad for Pakistan, it is also instrumental for NPT giving India complete freedom to continue and expand its fissile material for weapon, which is tantamount to virtually accepting it as a nuclear state. Therefore, Washington's

${ }^{77}$ R. Nicholas Burns, “America's Strategic Opportunity with India: The New US-India Partnership”, Foreign Affairs, November/December 2007.

${ }^{78}$ William J. Burns, "Statement to the Senate Foreign Relations Committee", 18 September 2008, <http://foreign.senate.gov>, 14 February 2009. 
strategic decision to build India into a major global player is evident from its policy towards the country. However, the pertinent fact is that this deal is at the expense of the India Pakistan balance of power. This deal will enable India to multiply its nuclear arsenal and India's growing arsenal will undermine Pakistan's security. Apart from the nuclear deal US invitation to India to involve itself more in Afghanistan is seen with insecurity by the Pakistani establishment.

It may not be ignored that unlike Pakistan, India has never accepted dictation from the US in this new partnership. Therefore, India is the equal partner and a kind of warmth is evident in Indo-US relations along with permanence of character. In political strategic terms, clearly India is being seen as the regional manager allied to the US. The important fact is that US-India relationship directly impacts and aggravates Pakistan's security milieu. For Pakistan, the India-US strategic partnership has a direct bearing on the Pakistan-US relationship. Notwithstanding the close cooperation between the US and' Pakistan in the pursuit of important objectives, especially the global war on terror, this has not resulted in the relationship acquiring a strategic dimension.

Pakistan has expressed its fears about the US-India nuclear deal. Pakistan's National Command Authority (NCA), chaired by President Pervez Musharraf, has declared: "In view of the fact the US-India agreement would enable India to produce a significant quantity of fissile material and nuclear weapons from unsafeguarded nuclear reactors, the NCA expressed firm resolve that our credible minimum deterrence requirements will be met." This suggests a South Asian fissile material race may be imminent. Such a race would be both dangerous and costly, and set back the efforts for peace and development in South Asia.

\section{Conclusion and Likely Future Policies}

US involvement in South Asia initially began in the Cold War era, a time when Washington was trying to win over camp followers or the two important and strategically located states, India and Pakistan, the former chose nonalignment whereas the latter, chose to be an ally of the United States. Fierce competition between the two super powers compelled policy makers to have allies and influence in 
every corner of the globe. The stunning growth of the United States has been fueled in good part by realist logic along with the need to prosper, benefit and expand economically as well as militarily. All this coupled with a powerful sense of ideological mission called for influence and expansion.

Although American foreign policy has remained overly independent in the post Cold War years, assertive unilateralism has been at the outset of the distinguishing feature of American foreign policy in the 21 st century. This unilateralism is not something new, as discussed in part one of this article. The new grand strategy's main features are unending war on terror, pre-emptive war and maintenance of the US supremacy. This grand strategy is driven by the neorealist school of thought and framed by the neocon strategists and military industrial complex advisors in the Bush administration.

As mentioned before, the Bush administration's general foreign policy departures, especially America's reliance on military force, its narrow ad hoc supporting coalitions, along with a hard line policy of pre-emption has made American foreign policy seem less defined and consistent. Prior to the September 11 terrorist attacks, policy makers in Washington treated India and Pakistan very differently and had very different perceptions about the two countries. Pakistan was viewed as a state, virtually on the brink of failure, where as India was being viewed as a rising power with decisive influence in the region. This acknowledgement of India was evident from President Bill Clinton's visit to South Asia in the year 2000, which gave a very clear message that India was to be the new partner in the region.

In order to make Pak-US relations sustainable and long term there is a need that their cooperation should not remain confined on war on terrorism. Their relations should be broad based. Every day changing statements of US leaders relating Pakistan's role in war on terrorism are creating doubts about the US commitment for long-term cooperation with Pakistan.

In Obama's view, Pakistan's war against terrorism will remain half-hearted and ineffective if Kashmir dispute remains unresolved and is allowed to linger on. In the event of non-resolution, it is thought, Pakistan will remain distracted by threat on its eastern borders with India than focusing on north western borders with 
Afghanistan. Terrorism cannot be dealt "without Pakistan's help" given the "porous and very difficult" nature of the land. ${ }^{79}$ Hence, in his view, a peaceful resolution of the Kashmir dispute is needed for peace and stability in South Asia and for enlisting better Pakistan's cooperation in the war against terrorism in Afghanistan and its own FATA regions.

Likely future policies are:

- There should be little doubt that any US President, belonging to any party (Democratic or Republican) will not tend to pursue the US "national" and "global interests." History is witness that the populist Woodrow Wilson, John Kennedy and Roosevelt did the same despite their pre-election attractive style and personal charisma.

- It is often said that the US government's policies are like a big sealiner which cannot make sharp turns. The new government under Obama will not be able to effect abrupt foreign policy changes as there is no major ideological divide between the Republicans and Democrats.

- Terrorism will remain high on the US agenda as an important threat for the next decade or so.

\footnotetext{
${ }^{79}$ <http://www.dawn.com/2008/11/04/ed.html>, 14 February 2009.
} 